University of Wollongong

Research Online

Sydney Business School - Papers

Faculty of Business and Law

2011

\title{
A literature analysis on business performance for SMES - subjective or objective measures?
}

Siti Nur 'Atikah Zulkiffli

University of Wollongong, snaz167@uowmail.edu.au

Nelson Perera

University of Wollongong,nperera@uow.edu.au

Follow this and additional works at: https://ro.uow.edu.au/gsbpapers

Part of the Business Commons

\section{Recommended Citation}

Zulkiffli, Siti Nur 'Atikah and Perera, Nelson: A literature analysis on business performance for SMES subjective or objective measures? 2011.

https://ro.uow.edu.au/gsbpapers/312

Research Online is the open access institutional repository for the University of Wollongong. For further information contact the UOW Library: research-pubs@uow.edu.au 


\title{
A literature analysis on business performance for SMES - subjective or objective measures?
}

\begin{abstract}
The study examines the basic research methodologies and approaches for assessing business performance. It provides a critical literature analysis on how perception-based evaluation can be used to evaluate performance, specifically for SMEs. The analysis of the literature covers articles from major journals related to the topic. The methodology followed during the conduct of this paper involves starting with the broad case of articles in general business performance measurement, then focusing on the indicators used to study SMEs. Next, the review screens the list, focusing on the differences between subjective and objective measures. The validity issue related to subjective measures is also discussed.
\end{abstract}

\section{Keywords \\ era2015 \\ Disciplines \\ Business}

\section{Publication Details}

Zulkiffli, S. \& Perera, N. (2011). A literature analysis on business performance for SMES - subjective or objective measures?. 2011 SIBR Conference on Interdisciplinary Business and Economics Research (pp. 1-9). Bangkok, Thailand: Society of Interdisciplinary Business Research (SIBR). 


\title{
A LITERATURE ANALYSIS ON BUSINESS PERFORMANCE FOR SMES - SUBJECTIVE OR OBJECTIVE MEASURES?
}

\author{
Siti Nur 'Atikah Zulkiffli' and Nelson Perera ${ }^{\mathrm{b}}$ \\ This paper has been double-blind peer reviewed by an international panel of SIBR
}

\begin{abstract}
$\underline{\text { Abstract }}$
The study examines the basic research methodologies and approaches for assessing business performance. It provides a critical literature analysis on how perceptionbased evaluation can be used to evaluate performance, specifically for SMEs. The analysis of the literature covers articles from major journals related to the topic. The methodology followed during the conduct of this paper involves starting with the broad case of articles in general business performance measurement, then focusing on the indicators used to study SMEs. Next, the review screens the list, focusing on the differences between subjective and objective measures. The validity issue related to subjective measures is also discussed.
\end{abstract}

Key words: business performance, subjective measures, objective measures, small and medium enterprises.

\section{Introduction}

Measuring business performance in today's economic environment is a critical issue for academic scholars and practising managers. In general, business performance is defined as "the operational ability to satisfy the desires of the company's major shareholders" (Smith \& Reece, 1999, p. 153), and it must be assessed to measure an organisation's accomplishment. Many studies examine the relationship of organisational practice and processes to affect the "bottom line", and vice versa (Wall et al., 2004). Attempts to examine the relationship between strategy and performance have been made for more than 20 years; many current studies also focus on this aspect. Scholars have examined the importance of performance evaluation and practices for an organisation (Dess \& Robinson, 1984; Sapienza et al., 1988; McGrath et al., 1995; Song et al., 2005; Gruber et al., 2010). Much research also focuses on the performance of small firms and, more recently, medium firms as well (Pelham \& Wilson, 1996; Jarvis et al., 2000; Alasadi \& Abdelrahim, 2008; Thomas et al., 2008).

Regular indicators used in measuring business performance are profit, return on investment (ROI), turnover or number of customers (Wood, 2006), design quality and product improvement (Laura et al., 1996). However, Mann and Kehoe (1994) and FrancoSantos et al. (2007) recommend measuring business performance through the business performance measurement (BPM) system, as it is an important tool within many research

\footnotetext{
${ }^{a}$ Corresponding author. University of Wollongong, Australia and Universiti Malaysia Terengganu, Malaysia. email: snaz167@uowmail.edu.au.

${ }^{\mathrm{b}}$ University of Wollongong, Australia. email: nperera@uowmail.edu.au
} 
areas, particularly in business and social science studies. This system analyses and investigates each quality that affects a firm's business performance, categorising business performance into two broad areas: operational business performance (OBP) and strategic business performance (SBP). The major function of the system is to focus on investigating all an organisation's functions at high and low levels of activity (Mann \& Kehoe, 1994); it is appropriately applied to measuring the performance of small and medium enterprises (SMEs). This system is also appropriate for both quantitative (for example, questionnaires) and qualitative (for example, structured interview) research methods.

SMEs are often very reluctant to publicly reveal their actual financial performance, and scholars have deliberated on the need for subjective measures (for example, the sevenpoint Likert scale in empirical research) in evaluating business performance. It is important to consider the aspects of differentiation that may be potentially confounded between subjective (also described as perceived/perception performance) and objective measures. Thus, this paper aims to analyse the related literature on how perception-based evaluation can be used to evaluate SMEs' performance.

The rest of this paper is organised as follows: Section 2 describes the review methodology, Section 3 discusses subjective and objective performance measures, Section 4 deliberates the validity of subjective performance measures and Section 5 concludes and suggests the future research directions.

\section{Review Methodology}

The literature examined for this paper consists of 22 articles from 13 journals, including six articles from the Strategic Management Journal and three articles from the International Journal of Operations \& Production Management. Table 1 shows the distribution of these articles with respect to journals.

Table 1: Distribution of the Articles with Respect to Journals

\begin{tabular}{|l|c|}
\hline \multicolumn{1}{|c|}{ Journal } & Quantity \\
\hline \hline American Journal of Small Business & 1 \\
\hline Education, Business and Society & 1 \\
\hline International Journal of Operations \& Production Management & 3 \\
\hline International Journal of Quality \& Reliability Management & 1 \\
\hline Journal of Business Venturing & 1 \\
\hline Journal of Operations Management & 1 \\
\hline Journal of Small Business and Entrepreneurship & 1 \\
\hline Journal of Small Business and Enterprise Development & 2 \\
\hline Journal of the Academy of Marketing Science & 1 \\
\hline Marketing Bulletin & 1 \\
\hline Personnel Psychology & 2 \\
\hline Strategic Management Journal & 6 \\
\hline Supply Chain Management: An International Journal & 1 \\
\hline
\end{tabular}




\section{Subjective and Objective Performance Measures}

Many studies show a preference for subjective measures during the assessment of business performance due to difficulties in obtaining objective financial data. Managers often refuse to provide accurate, objective performance data to researchers. Even if objective data is made available, the data often do not fully represent firms' actual performance, as managers may manipulate the data to avoid personal or corporate taxes (Dess \& Robinson, 1984; Sapienza et al., 1988). Research on SMEs is particularly susceptible to these difficulties, although difficulties can also occur when the research examines business units of multi-industry and privately held firms (Dess \& Robinson, 1984).

Consequently, managers are often encouraged to evaluate business performance through general subjective measures that can reflect more-specific objective measures (Wall et al., 2004). Subjective measures can be an effective way to examine business performance, as they allow comparison across firms and contexts, such as industry type, time horizons, cultures or economic conditions (Song et al., 2005). When subjective measures are employed, managers can use the relative performance of their industry as a benchmark when providing a response (Dawes, 1999). Objective performance measures, in contrast, can vary based on industry and can obscure the relationship between independent variables and business performance (as a dependent variable) (Dawes, 1999).

Moreover, the objective data available to the researcher may not be compatible with the intended level of analysis (Wall et al., 2004); in these cases, subjective data can be a good alternative if the measures focus on the firm's current condition (for example, Kim, 2006a; Kim, 2006b).

It is legal for small firms' managers to manipulate some data, and to control such manipulation through subjectively adjusting measures (Sapienza et al., 1988). Moreover, many managers of small and private firms consider objective performance measures to be confidential, and guard them from public scrutiny (Sapienza et al., 1988; Gruber et al., 2010). Such managers tend to have a low level of awareness about the desirability of providing accurate and reliable data and feedback to researchers. Therefore, researchers are advised to develop subjective measures, as these provide more complete information (Covin \& Slevin, 1989).

Another issue in researching small firms is the difficulty of interpreting some objective performance data. For example, performance may be considered as "poor" if the data shows losses or low profit. Such misinterpretation can occur if, for example, firms have many commitments to research and development (R\&D), including product and market development for future growth (Covin \& Slevin, 1989). These misinterpretations may be due to variations in profitability data and may lead to the comparison of objective measures among small firms in different industries (Covin \& Slevin, 1989; Dawes, 1999). To avoid these sorts of issues, researchers have used subjective measures and focused on firms within the same industry (for example, manufacturing) (Appendix A).

Table 2 outlines some differences between subjective and objective performance measures. 
Table 2: Differences between Subjective and Objective Measure in Business Performance

\begin{tabular}{|l|l|l|}
\hline $\begin{array}{c}\text { Differentiation } \\
\text { Aspect }\end{array}$ & \multicolumn{1}{|c|}{ Subjective Measures } & \multicolumn{1}{|c|}{ Objective Measures } \\
\hline Indicators & $\bullet$ Focus on overall performance & $\begin{array}{l}\text { - Focus on actual financial } \\
\text { indicators }\end{array}$ \\
\hline $\begin{array}{l}\text { Measurement } \\
\text { standard }\end{array}$ & $\begin{array}{l}\text { - Key informants are asked to } \\
\text { rate performance relative to } \\
\text { their competitors (and/or } \\
\text { industry) }\end{array}$ & $\begin{array}{l}\text { - Key informants should provide } \\
\text { absolute financial data (for } \\
\text { example, AUD profit per } \\
\text { employee) }\end{array}$ \\
\hline Scale anchors & $\begin{array}{l}\text { - Scales range from "very poor" } \\
\text { to "very good", or "much } \\
\text { lower" to "much higher", or } \\
\text { "worst in industry" to "best in } \\
\text { industry" etc. }\end{array}$ & - Scales are not used \\
\hline
\end{tabular}

Source: Adapted from Dawes (1999), Wall et al. (2004) and Kim (2006b)

\section{The Validity of Subjective Performance Measures}

Subjective measurements are strongly correlated with objective measurements in terms of absolute changes in return on assets and sales over the same time period; for example, the correlation $(r)$ of objective and subjective measures to total sales gives a value for $r$ of .80, and to return on assets gives a value of .79 (Dess \& Robinson, 1984). These findings support the validity of performance evaluation through subjective measures.

However, less attention has been given to evaluating the validity of subjective performance measurement. Such measurements, which are subject to potential measurement errors and bias, have been examined using several types of validity tests (Chandler \& Hanks, 1993; Wall et al., 2004). Three validity tests - convergent, discriminant and construct - have been used to show that subjective measurement is significantly reliable as an alternative to objective measurement in business performance.

Table 3 shows the result of validity tests related to subjective measurement in business performance.

Table 3: Results of Different Validity Tests to Measure Business Performance

\begin{tabular}{|l|l|}
\hline \multicolumn{1}{|c|}{ Validity Type } & \multicolumn{1}{c|}{ Results } \\
\hline \hline Convergent & $\begin{array}{l}\text { - Subjective performance measures are related to objective } \\
\text { measures. }\end{array}$ \\
\hline Discriminant & $\begin{array}{l}\text { - Relationships between subjective and objective measures are } \\
\text { systematically stronger than relationships between different } \\
\text { performance constructs measured using the same method (either } \\
\text { subjective or objective). }\end{array}$ \\
\hline Construct & $\begin{array}{l}\text { - Relationships between subjective and objective performance } \\
\text { measures with a series of independent variables are equivalent. }\end{array}$ \\
& $\begin{array}{l}\text { - Subjective performance measurement has a statistically significant } \\
\text { correlation with objective measurement }(p<.01) .\end{array}$ \\
& $\begin{array}{l}\text { Subjective measurement shows a 95\% success rate as compared } \\
\text { with objective measurement. }\end{array}$ \\
\hline
\end{tabular}

Source: Adapted from Wall et al. (2004) 
The findings of Wall et al. (2004) support the earlier studies that discuss the validation of performance measurement (Hoffman et al., 1991; Chandler \& Hanks, 1993). Chandler and Hanks's 1993 study - supported by Lee et al. (2001) - discussed the validation issues for another three measurement aspects: broadly defined categories, managers' satisfaction with performance and firm performance relative to competitors. Results showed a high level of correlation between objective and subjective measures, as well as suggesting strong inter-rater reliability (Lee et al., 2001).

Table 4 shows the results of comparison between performance measures that can be used in related studies.

Table 4: Summary Comparison of Performance Measures

\begin{tabular}{|c|c|c|c|c|}
\hline & \multicolumn{2}{|c|}{ Broadly Defined Categories } & \multirow{2}{*}{$\begin{array}{l}\text { Performance } \\
\text { Relative to } \\
\text { Competitors }\end{array}$} & \multirow{2}{*}{$\begin{array}{c}\text { Satisfaction } \\
\text { with } \\
\text { Performance }\end{array}$} \\
\hline & Growth & $\begin{array}{l}\text { Business } \\
\text { Volume }\end{array}$ & & \\
\hline Relevance & Very Good & Very Good & Very Good & Unknown \\
\hline Availability & Very Good & Very Good & Acceptable & Very Good \\
\hline Internal Consistency & Good & Very Good & Very Good & Good \\
\hline Inter-rater Reliability & Good & Very Good & Marginal & Acceptable \\
\hline External Validity & Very Good & Very Good & Very Good & Inadequate \\
\hline
\end{tabular}

Source: Chandler and Hanks (1993)

The table shows that broadly defined categories and performance relative to competitors are still useful. However, Chandler and Hanks (1993, p. 400) explain that, “... in reference to the 'performance relative to competitors' scale, several respondents who did not disclose performance relative to competitors' information pencilled in that they had no basis for comparison because they did not know how their competitors were performing". This suggests that examination of performance relative to competitors should be focused on the entire industry to assess "generalisability", as some respondents may not know much about their competitors' performance.

\section{Conclusions and Future Research Directions}

Examination of the literature on this topic offers guidance in how the various business performance measures in an SME can be organised, interfaced and managed. The literature suggests that subjective evaluations are appropriate alternatives to objective measurement.

It is difficult for researchers to accurately estimate performance, particularly when using mailed questionnaires, as the data will be subject to measurement errors caused by the confidential nature of the data and variance in accounting procedures among participating firms (Dess \& Robinson, 1984). Also, managers do prefer to provide such data subjectively to protect confidentiality (Song et al., 2005).

The literature also shows that the evaluation of subjective perceptions is commonly and comprehensively used in social-science research (Pelham \& Wilson, 1996; Kim, 2006b; Yong et al., 2007; Alasadi \& Abdelrahim, 2008; Gruber et al., 2010); the use of such measures to evaluate performance is acceptable, as it shows high positive correlations with objective measures (Song et al., 2005). However, the equivalence assumptions between subjective and objective performance measures are still being debated.

Future research should endeavour to develop new measurement and performance systems that focus on SMEs and the application of subjective measures. Additionally, future 
studies may also need to establish more precise frameworks and empirical testing for performance measures. The contribution of this study has been in examining and expanding the taxonomy of business performance and in shedding light on future research in any discipline that focuses on measuring performance. 


\section{Appendix A:}

\section{Example of a Research Questionnaire Measuring Business Performance}

Listed below are statements describing the business performance of a firm. These statements are divided into five sections: Market, Suppliers, Process, People and Customer Relationships measures. How would you rate your firm's actual current conditions of business performance relative to the major industry competitors? Please remember that there are no right or wrong answers and the information you provide will be kept confidential.

\begin{tabular}{|c|c|c|c|c|c|c|}
\hline \multicolumn{2}{|c|}{ Scale } \\
\hline $\begin{array}{c}\text { Worst in } \\
\text { the } \\
\text { Industry }\end{array}$ & $\begin{array}{c}\text { Worse in the } \\
\text { Industry }\end{array}$ & $\begin{array}{c}\text { Bad in the } \\
\text { Industry }\end{array}$ & Neutral & $\begin{array}{c}\text { Good in the } \\
\text { Industry }\end{array}$ & $\begin{array}{c}\text { Better in } \\
\text { the } \\
\text { Industry }\end{array}$ & $\begin{array}{c}\text { Best in the } \\
\text { Industry }\end{array}$ \\
\hline 1 & 2 & 3 & 4 & 5 & 6 & 7 \\
\hline
\end{tabular}

Market Performance

E1 Market-share growth

E2 Sales turnover

$\begin{array}{lllllll}1 & 2 & 3 & 4 & 5 & 6 & 7\end{array}$

$\begin{array}{lllllll}1 & 2 & 3 & 4 & 5 & 6 & 7\end{array}$

Supplier Performance

E3 Supplier product quality

E4 Suppler communication

E5 Supplier delivery performance

Process Performance

E6 Work in process (WIP) ${ }^{*}$ inventory

E7 Order-fulfilment lead time ${ }^{* *}$

E8 Product-quality development

People Performance

E9 Performance-appraisal results

E10 Skill level of employees

E11 Departmental communication

Customer-Relationship Performance

E12 Resolution of customer complaints $\quad \begin{array}{lllllll} & 2 & 3 & 4 & 5 & 6 & 7\end{array}$

E13 Customer loyalty/retention

$\begin{array}{lllllll}1 & 2 & 3 & 4 & 5 & 6 & 7\end{array}$

E14 Quality reputation and award achievement

$\begin{array}{lllllll}1 & 2 & 3 & 4 & 5 & 6 & 7\end{array}$

E15 Product returns rate

E16 The speed of order handling and processing

*Work-in-Process (WIP) relates to the products or components that are no longer raw material but have yet to become finished products.

**Lead time is the time between placement and receipt of an order. 


\section{References}

Alasadi, R. \& Abdelrahim, A. (2008). Analysis of small business performance in Syria. Education, Business and Society: Contemporary Middle Eastern Issues, 1(1): 50-62.

Chandler, G. N. \& Hanks, S. H. (1993). Measuring the performance of emerging businesses: A validation study. Journal of Business Venturing, 8(5): 391-408.

Covin, J. G. \& Slevin, D. P. (1989). Strategic management of small firms in hostile and benign environments. Strategic Management Journal, 10(1): 75-87.

Dawes, J. (1999). The relationship between subjective and objective company performance measures in market orientation research: Further empirical evidence. Marketing Bulletin, 10: 65-76.

Dess, G. G. \& Robinson, J. R. B. (1984). Measuring organizational performance in the absence of objective measures: The case of the privately-held firm and conglomerate business unit. Strategic Management Journal (pre-1986), 5(3): 265-273.

Franco-Santos, M., Kennerley, M., Micheli, P., Martinez, V., Mason, S., Marr, B., Gray, D. \& Neely, A. (2007). Towards a definition of a business performance measurement system. International Journal of Operations \& Production Management, 27(8): 784801.

Gruber, M., Heinemann, F., Brettel, M. \& Hungeling, S. (2010). Configurations of resources and capabilities and their performance implications: An exploratory study on technology ventures. Strategic Management Journal, 31(12): 1337-1356.

Hoffman, C. C., Nathan, B. R. \& Holden, L. M. (1991). A comparison of validation criteria: Objective versus subjective performance measures and self-versus-supervisor ratings. Personnel Psychology, 44(3): 601-619.

Jarvis, R., Curran, J., Kitching, J. \& Lightfoot, G. (2000). The use of quantitative and qualitative criteria in the measurement of performance in small firms. Journal of Small Business and Enterprise Development, 7(2): 123 - 134.

Kim, S. W. (2006a). The effect of supply chain integration on the alignment between corporate competitive capability and supply chain operational capability. International Journal of Operations \& Production Management, 26(10): 1084-1107.

Kim, S. W. (2006b). Effects of supply chain management practices, integration and competition capability on performance. Supply Chain Management: An International Journal, 11(3): 241-248.

Laura, B. F., Shawnee, K. V. \& Cornelia, L. M. D. (1996). The contribution of quality to business performance. International Journal of Operations \& Production Management, 16(8): 44-62. 
Lee, C., Lee, K. \& Pennings, J. M. (2001). Internal capabilities, external networks, and performance: A study on technology-based ventures. Strategic Management Journal, 22(6-7): 615-640.

Mann, R. \& Kehoe, D. (1994). An evaluation of the effects of quality improvement activities on business performance. International Journal of Quality \& Reliability Management, 11(4): 29-44.

McGrath, R. G., MacMillan, I. C. \& Venkataraman, S. (1995). Defining and developing a competence: A strategic process paradigm. Strategic Management Journal, 16(4): 251-275.

Pelham, A. M. \& Wilson, D. T. (1996). A longitudinal study of the impact of market structure, firm structure, strategy, and market orientation culture on dimensions of small-firm performance. Journal of the Academy of Marketing Science., 24(1): 27-43.

Sapienza, H. J., Smith, K. G. \& Gannon, M. J. (1988). Using subjective evaluations of organizational performance in small business research. American Journal of Small Business, 12(3): 45-53.

Smith, T. M. \& Reece, J. S. (1999). The relationship of strategy, fit, productivity, and business performance in a services setting. Journal of Operations Management, 17(2): $145-161$.

Song, M., Droge, C., Hanvanich, S. \& Calantone, R. (2005). Marketing and technology resource complementarity: An analysis of their interaction effect in two environmental contexts. Strategic Management Journal, 26(3): 259-276.

Thomas, W. Y. M., Theresa, L. \& Ed, S. (2008). Entrepreneurial Competencies and the Performance of Small and Medium Enterprises: An Investigation through a Framework of Competitiveness. Journal of Small Business and Entrepreneurship, 21(3): 257.

Wall, T. D., Michie, J., Patterson, M., Wood, S. J., Sheehan, M., Clegg, C. W. \& West, M. (2004). On the validity of subjective measures of company performance. Personnel Psychology, 57(1): 95-118.

Wood, E. H. (2006). The internal predictors of business performance in small firms. Journal of Small Business and Enterprise Development, 13(3): 441-452.

Yong, T., Shi-hua, M. \& Feng-mei, G. (2007). Empirical study on impact of logistics operations capability on supply chain performance. The 3rd International Conference on Wireless Communications, Networking, and Mobile Computing (WiCOM) 2007. Shanghai, P.R. China. 